\title{
Soft Tissue Sarcoma of the Retroperitoneum pTX TNM Finding v8
}

National Cancer Institute

\section{Source}

National Cancer Institute. Soft Tissue Sarcoma of the Retroperitoneum PTXTNM

Finding v8. NCI Thesaurus. Code C136801.

Soft tissue sarcoma of the retroperitoneum in which the primary tumor cannot be assessed. (from AJCC 8th Ed.) 